\title{
PENERAPAN MODEL PEMBELAJARAN INQUIRY UNTUK MENINGKATAN HASIL BELAJAR PKN TENTANG KEBEBASAN BERORGANISASI
}

\author{
Kanti Pristiwati \\ Sekolah Dasar Negeri Rembang 2 Kota Blitar \\ Jalan Akasia Nomor 17 Kota Blitar \\ Email: kantipristiwati66@gmail.com
}

\begin{abstract}
Application of Inquiry Learning Model for Improving Learning Outcomes of Civic Education About the Freedom to Organize. The purpose of this research are: (1) describe the application of inquiry learning model that can improve learning outcomes; and (2) describe the learning outcome of students in the subjects of Civic Education on Freedom to Organize the inquiry learning model can improve student learning outcomes Class V SDN Rembang 2 of Blitar. This type of research is the Classroom Action Research, and carried out in two cycles. Each cycle consists of four phases: planning, implementation, observation, and reflection. The results showed that the implementation of inquiry learning model can improve the activity of the teacher, student activities, and student learning outcomes. This is evident from the acquisition value of the average student learning outcomes which have been steadily increasing from the first cycle was 73, and in Cycle II to 83. In addition the percentage of completeness of students in the first cycle was $58 \%$ and the second cycle reaches $87,5 \%$.
\end{abstract}

Keywords: inquiry learning model, learning outcomes

\begin{abstract}
Abstrak: Penerapan Model Pembelajaran Inquiry Untuk Meningkatan Hasil Belajar Pkn Tentang Kebebasan Berorganisasi. Tujuan penelitian ini adalah: (1) mendeskripsikan penerapan model pembelajaran inquiry yang dapat meningkatkan hasil belajar; dan (2) mendeskripsikan peningkatan hasil belajar siswa dalam mata pelajaran Pendidikan Kewarganegaraan tentang Kebebasan Berorganisasi dengan model pembelajaran inquiry dapat meningkatkan hasil belajar siswa Kelas V SDN Rembang 2 Kota Blitar. Jenis penelitian yang digunakan adalah Penelitian Tindakan Kelas (PTK), dan dilaksanakan dalam 2 siklus. Setiap siklus terdiri dari 4 tahapan yaitu perencanaan, pelaksanaan, observasi, dan refleksi. Hasil penelitian menunjukkan bahwa penerapan model pembelajaran inquiry dapat meningkatkan aktivitas guru, aktivitas siswa, dan hasil belajar siswa. Hal ini terlihat dari perolehan nilai rata-rata hasil belajar siswa yang mengalami peningkatan secara bertahap mulai dari Siklus I sebesar 73, dan pada Siklus II menjadi 83. Selain itu persentase ketuntasan belajar siswa pada Siklus I sebesar $58 \%$ dan pada siklus II mencapai 87,5\%.
\end{abstract}

Kata kunci: model pembelajaran inquiry, hasil belajar

Proses belajar mengajar merupakan interaksi yang dilakukan antara guru dan siswa dalam suatu situasi pendidikan atau pengajaran untuk mewujudkan tujuan yang ingin dicapai. Tujuan belajar mengajar tersebut ialah untuk membentuk siswa dalam suatu perkembangan tertentu (Djamarah dan Zain, 1995:46). Perkembangan yang diharapkan dalam proses belajar ialah adanya perubahan yang terjadi setelah kegiatan pembelajaran berlangsung. Belajar dianggap sebagai proses perubahan perilaku sebagai 
akibat dari pengalaman dan latihan siswa. Belajar bukanlah sekadar mengumpulkan pengetahuan saja, namun juga memahami pengetahuan yang diterima. Sanjaya (2009:112) menyatakan belajar adalah proses mental yang terjadi dalam diri seseorang, sehingga menyebabkan munculnya perubahan perilaku.

Pelajaran Pendidikan Kewarganegaraan (PKn), dengan materi pelajaran yang cukup padat dan perubahan kurikulum karena mengikuti perkembangan pemerintahan, juga menjadi beban yang cukup berat bagi siswa untuk dapat berhasil secara maksimal. Siswa kurang berminat dalam mengikuti pelajaran pendidikan kewarganegaraan. Hasil yang diperoleh selalu kurang sesuai dengan yang diharapkan. Kaitannya dengan pembentukan warga negara Indonesia yang demokratis dan bertanggung jawab, matapelajaran PKn memiliki peranan yang strategis dan penting, yaitu dalam membentuk siswa maupun sikap dalam berperilaku keseharian, sehingga diharapkan setiap individu mampu menjadi pribadi yang baik. Minat belajar siswa pada bidang PKn ini perlu mendapat perhatian khusus karena minat merupakan salah satu faktor penunjang keberhasilan proses belajar. Di samping itu minat yang timbul dari kebutuhan siswa merupakan faktor penting bagi siswa dalam melaksanakan kegiatan-kegiatan atau usahanya.

PKn bertujuan untuk mengembangkan potensi individu warga negara Indonesia sehingga memiliki wawasan, sikap, dan keterampilan kewarganegaraan yang memadai dan memungkinkan untuk berpartisipasi secara cerdas dan bertanggung jawab dalam berbagai dimensi kehidupan bermasyarakat, berbangsa, dan bernegara (Tim Puskur, 2006). Pengalaman mengajar pembelajaran PKn masih menghadapi banyak kendala-kendala. Kendala-kendala yang dimaksud antara lain: (1) anak mudah bosan; (2) materi PKn yang luas dan bersifat hafalan; (3) setiap kali mengikuti kegiatan belajar siswa mudah mengantuk, dan bergurau sendiri; dan (4) hasil belajar siswa rendah, banyak yang masih di bawah KKM, dari 40 siswa hanya 14 siswa (35\%) yang telah tuntas, selebihnya 26 siswa (65\%) belum tuntas belajar. Hal ini dikarenakan dalam melaksanakan kegiatan pembelajaran guru: (1) menggunakan model pembelajaran konvensional; (2) tidak menggunakan media pembelajaran; dan(3) materi hanya mengerjakan LKS. Akibatnya timbul kesenjangan yaitu siswa tidak dapat memahami bagaimana mengenal cara berorganisasi yang baik.

Untuk mengatasi permasalahan tersebut guru harus mengubah pola atau proses pembelajaran, yaitu dengan menggunakan sebuah model pembelajaran inquiry. Model pembelajaran inquiry merupakan salah satu strategi yang digunakan dalam kelas yang berorientasi proses. Sanjaya (2006:194) menyatakan strategi pembelajaran inquiry adalah rangkaian kegiatan pembelajaran yang menekankan pada proses berpikir secara kritis dan analisis untuk mencari dan menemukan sendiri jawaban dari suatu masalah yang dipertanyakan. Siswa dengan bimbingan guru, diberikan kesempatan untuk mencari sendiri konsepnya inquiry merupakan sebuah strategi pengajaran yang berpusat pada siswa, yang mendorong siswa untuk menyelidiki masalah dan menemukan informasi. Proses tersebut sama dengan prosedur yang digunakan oleh ilmuwan sosial yang menyelidiki masalah-masalah dan menemukan informasi (Bruce dan Cleaf, 1991). Pengajaran berdasarkan inquiry adalah suatu model yang berpusat pada siswa di mana kelompok-kelompok siswa dihadapkan pada suatu persoalan atau mencari jawaban terhadap pertanyaan-pertanyaan di dalam suatu prosedur dan struktur kelompok yang digariskan secara jelas (Hamalik, 1991).

Berdasarkan observasi yang dilakukan pada matapembelajaran PKn Kelas V DN Rembang 2 Kota Blitar, menunjukkan bahwa masih terdapat beberapa permasalahan pada aktivitaas guru, yaitu: (1) guru tidak membimbing siswa dalam menyusun laporan, sehingga kesimpulan yang disusun siswa hanya asal-asalan saja; (2) guru tidak membimbing siswa dalam menyampaikan laporan, sehingga dalam kegiatan diskusi kelas siswa pasif; dan (3) guru tidak membimbing siswa dalam menyusun hasil pengamatan. Sedangkan permasalahan yang muncul pada aktifitas siswa, yaitu: (1) tidak nampak kegiatan berdiskusi siswa dalam pembelajaran; (2) tidak tampak siswa melakukan keegiatan menyusun hipotesis; (3) tidak nampak siswa memberikan tanggapan terhadap hasil laporan kelompok; dan (4) dua siswa menyusun kesimpulan dengan asal-asalan. Untuk itu perlu diadakan pembaharuan dalam penggunaan model pembelajaran. 
Model inquiry merupakan suatu proses yang ditempuh siswa untuk memecahkan masalah, merencanakan eksperimen, melakukan eksperimen, mengumpulkan dan menganalisis data, dan menarik kesimpulan. Model inquiry melibatkan siswa secara mental maupun fisik untuk memecahkan suatu permasalahan yang diberikan guru. Siswa dengan demikian akan terbiasa bersikap seperti para ilmuan, yaitu teliti, tekun, ulet, objektif, jujur, kreatif, dan menghormati pendapat orang lain.

\section{METODE}

Pendekatan yang digunakan dalam penelitian ini adalah pendekatan kualitatif. Sedangkan jenis penelitian yang digunakan dalam penelitian ini adalah penelitian tindakan kelas (PTK) yaitu sebuah kegiatan penelitian yang dilakukan di kelas (Arikunto, 2007:2). Penelitian ini dilakukan untuk memecahkan permasalahan yang muncul saat pembelajaran berlangsung. Selain itu juga menggambarkan bagaimana suatu teknik pembelajaran diterapkan, serta bagaimana hasil yang diinginkan dapat dicapai. Penelitian ini dilaksanakan di SDN Rembang 2 Kota Blitar. Penelitian dirancang selama 2 siklus, masingmasing siklus dilaksanakan selama dua kali pertemuan. Waktu yang dibutuhkan setiap pertemuan adalah 2 × 35 menit. Subyek Penelitian adalah guru dan siswa Kelas V SDN Rembang 2 Kota Blitar. Jumlah siswa kelas V adalah 40 siwa, yang terdiri dari 22 laki-laki dan 18 perempuan.

Teknik analisis data dilakukan setelah melakukan tindakan pada masing-masing siklus yang telah dilakukan. Teknik analisis data yang dilakukan pada penelitian ini adalah teknik analisis data kualitatif yaitu menggambarkan kenyataan atau data sesuai dengan data yang diperoleh dengan tujuan untuk mengetahui peningkatan hasil belajar pembelajaran PKn serta sejauh mana siswa mampu memunculkan sikap rasa keingintahuannya dalam pembelajaran. Langkah-langkah analisis terdiri dari tiga alur kegiatan yang terjadi secara bersamaan yaitu: (1) reduksi data; (2) penyajian data; (3) penarikan kesimpulan.

\section{HASIL}

\section{Siklus I}

Berdasarkan hasil observasi pada Siklus I diketahui kegiatan guru saat pembelajaran PKn tentang kebebasan berorganisasi mengalami peningkatan dari pertemuan 1 ke pertemuan 2. Pertemuan 1 keterlaksanaan aspek inquiry mencapai 5 dengan persentase nilai rata-rata kegiatan guru adalah $63 \%$ dengan kriteria tingkat keberhasilan cukup. Pada pertemuan 2 keterlaksanaan aspek inquiry naik 1 poin menjadi 6 , persentase nilai rata-rata meningkat menjadi 75\% dengan kriteria tingkat keberhasilan baik. Pada pertemuan 2 ini berarti persentase aktivitas guru naik $12 \%$ dari pembelajaran pertemuan 1 . Pada kegiatan pembelajaran melalui model inquiry pada siklus I guru sudah cukup baik, namun guru masih kesulitan mengelola kelas sehingga ada beberapa aspek inquiry yang masih belum dapat dilaksanakan oleh guru, untuk itu perlu adanya perbaikan pada Siklus II.

Pada pelaksanaan Siklus I diketahui bahwa kegiatan siswa pada pembelajaran PKn tentang kebebasan berorganisasi mengalami peningkatan dari pertemuan 1 ke pertemuan 2. Pertemuan 1 keterlaksanaan aktivitas siswa selama mengikuti pembelajaran dengan model inquiry mencapai 6 dengan persentase nilai rata-rata aktifitas siswa yang dilakukan adalah $60 \%$ dengan kriteria tingkat keberhasilan cukup. Pada pertemuan 2 keterlaksanaan aktivitas siswa selama mengikuti pembelajaran dengan model inquiry naik 1 poin menjadi 7 , persentase nilai rata-rata meningkat menjadi $70 \%$ dengan kriteria tingkat keberhasilan cukup. Pada pertemuan 2 ini berarti persentase aktivitas siswa selama mengikuti pembelajaran dengan model inquiry naik $10 \%$ dari pembelajaran pertemuan 1. Pada kegiatan pembelajaran melalui model inquiry pada Siklus I aktivitas siswa sudah cukup baik, namun masih ada beberapa siswa yang hanya bermain-main saat kegiatan diskusi kelompok, dan juga siswa masih kesulitan ketika diarahkan untuk menyusun kesimpulan pembelajaran, untuk itu perlu adanya perbaikan pada Siklus II. 
Kegiatan observasi juga dilakukan pada aspek psikomotor siswa ketika melakukan diskusi kelompok.Berdasarkan haasil pengamatan yang dilakukan pada Siklus I pertemuan 1 dan 2, diperoleh data hasil pengamatan sikap siswa tuntas dalam gagasan, kesesuaian menjawab, dan partisipasi dalam kegiatan pembelajaran pada pertemuan pertama yaitu sejumlah 20 anak, dan yang belum tuntas tuntas sejumlah 20 anak. Dengan nilai rata-rata siswa mencapai 69 . Secara klasikal, dalam pembelajaran Siklus I pada pertemuan pertama siswa yang telah aktif dalam kegiatan pembelajaran adalah sebesar $50 \%$.

Pada Siklus I pertemuan kedua, pengamatan sikap siswa tuntas dalam keaktifan, kerjasama, dan ketepatan dalam memberikan jawaban pada saat kegiatan pembelajaran sejumlah 26 anak, dan yang belum tuntas tuntas dalam kegiatan aktifitas belajar sejumlah 14 anak, dengan nilai rata-rata mencapai 77. Secara klasikal, dalam pembelajaran siklus I pada pertemuan kedua siswa yang telah aktif dalam kegiatan pembelajaran adalah sebesar $65 \%$. Tingkat hasil belajar yang diperoleh siswa pada Siklus I, mencapai kategori cukup. Pada pertemuan pertama, ketuntasan belajar siswa hanya mencapai 21 siswa, sedangkan 19 siswa yang lain belum tuntas belajar. Dengan persentase keberhasilan sebesar 52,5\%. Pada pertemuan kedua, terjadi peningkatan hasil belajar, dengan jumlah siswa yang tuntas belajar mencapai 25 anak, sedangkan 15 anak masih belum tuntas belajar. Adapun persentase ketuntasan belajar pada siklus I tersebut adalah sebesar $62,5 \%$.

\section{Siklus II}

Berdasarkan hasil pengamatan diketahui kegiatan guru pada pembelajaran PKn tentang kebebasan berorganisasi mengalami peningkatan dari Siklus I. Pertemuan 1 keterlaksanaan aspek inquiry mencapai 7 dengan persentase nilai ratarata kegiatan guru adalah $88 \%$ dengan kriteria tingkat keberhasilan sangat baik. Pada pertemuan 2 keterlaksanaan aspek inquiry tetap pada angka 10, persentase nilai rata-rata meningkat menjadi $100 \%$ dengan kriteria tingkat keberhasilan sangat baik. Pada siklus II ini berarti persentase aktivitas guru naik dari siklus I. rata-rata pencapaian persentase pada siklus II ini mencapai 94\%, dengan kriteria sangat baik. Pada kegiatan pembelajaran melalui model inquiry pada siklus II guru sudah sangat baik dalah melaksanakan tahap-tahap inquiry, guru mampu dengan baik mengelola kelas, seluruh aspek inquiry dapat dilaksanakan oleh guru.

Kegiatan siswa pada pembelajaran PKn tentang kebebasan berorganisasi pada siklus II mengalami peningkatan dari pertemuan 1 ke pertemuan 2. Pertemuan 1 keterlaksanaan aktivitas siswa selama mengikuti pembelajaran dengan model inquiry mencapai 9 dengan persentase nilai rata-rata aktifitas siswa yang dilakukan adalah 90\% dengan kriteria tingkat keberhasilan baik. Pada pertemuan 2 keterlaksanaan aktivitas siswa selama mengikuti pembelajaran dengan model inquiry naik 1 poin menjadi 10 , persentase nilai rata-rata meningkat menjadi $100 \%$ dengan kriteria tingkat keberhasilan sangat baik. Pada pertemuan 2 ini berarti persentase aktivitas siswa selama mengikuti pembelajaran dengan model inquiry naik $10 \%$ dari pembelajaran pertemuan 1. Pada kegiatan pembelajaran melalui model inquiry pada Siklus II aktivitas siswa sudah sangat baik. Rerata aktifitas siswa pada siklus II mencapai nilai 95 dengan kategori sangat baik.

Di samping pengamatan aktifitas siswa, observasi juga dilakukan pada aspek psikomotor siswa ketika melakukan diskusi kelompok. Berdasarkan hasil pengamatan yang dilakukan pada Siklus II pertemuan 1 dan 2, diperoleh data hasil pengamatan sikap siswa tuntas dalam gagasan, ketepatan jawaban, dan partisipasi dalam kegiatan pembelajaran pada pertemuan pertama yaitu sejumlah 33 anak, dan yang belum tuntas tuntas sejumlah 7 anak. Dengan nilai rata-rata siswa mencapai 81. Secara klasikal, dalam pembelajaran siklus II pada pertemuan pertama siswa yang telah aktif dalam kegiatan pembelajaran adalah sebesar $83 \%$. Pada siklus II pertemuan kedua, pengamatan sikap siswa tuntas dalam keaktifan, kerjasama, dan ketepatan dalam memberikan jawaban pada saat kegiatan pembelajaran sejumlah 38 anak, dan yang belum tuntas tuntas dalam kegiatan aktifitas belajar sejumlah 2 anak. Dengan nilai rata-rata mencapai 91.

Secara klasikal, dalam pembelajaran siklus II pada pertemuan kedua siswa yang telah aktif dalam kegiatan pembelajaran adalah sebesar 95\%. Tingkat hasil belajar yang diperoleh siswa pada Siklus I, mencapai kategori sangat baik. Pada 
pertemuan pertama, ketuntasan belajar siswa hanya mencapai 32 siswa, sedangkan 8 siswa yang lain belum tuntas belajar. Dengan persentase keberhasilan sebesar $80 \%$. Pada pertemuan kedua, terjadi peningkatan hasil belajar, dengan jumlah siswa yang tuntas belajar mencapai 37 anak, sedangkan 3 anak masih belum tuntas belajar. Adapun persentase ketuntasan belajar pada siklus I tersebut adalah sebesar 92,5\%.

Pelaksanaan pembelajaran menggunakan model pembelajaran inquiry mempengaruhi aktivitas siswa dalam kegiatan pembelajaran. Interaksi dan kerjasama antarsiswa mulai merata, siswa mulai terlibat aktif dalam kegiatan diskusi untuk menemukan jawaban suatu masalah (dengan bimbingan guru). Peningkatan aktivitas belajar siswa ini dapat dibuktikan yaitu pada kegiatan siklus I mencapai $66 \%$ pada kegiatan siklus I, dan $82,5 \%$ pada Siklus II.

Berdasarkan hasil observasi dan refleksi dari penerapan model pembelajaran inquiry terhadap kegiatan pembelajaran pendidikan kewarganegaraan rata-rata persentase aktifitaas guru, aktifitas siswa, dan ketuntasan belajar siswa meningkat pada tiap siklusnya. Adapun peningkatan aktifitas guru dan aktifitas siswa pada tiap siklusnya dapat diketahui pada Tabel 1.

Berdasarkan Tabel 1 diketahui bahwa aktifitas guru meningkat pada tiap siklusnya, yaitu pada Siklus I pertemuan pertama aktifitas guru hanya mencapai $50 \%$, pada pertemuan kedua mencapai $67 \%$ dengan rata-rata aktofitas guru pada siklus I mencapai 59\%. Pada Siklus II, aktifitas guru yang dicapai pada pertemuan pertama mencapai $100 \%$, begitu pula pada pertemuan kedua mencapai $100 \%$, sehingga rata-rata aktifitas guru pada siklus kedua mencapai $100 \%$. Peingkatan aktifitas guru tersebut, berpengaruh pada aktifitas siswa yang juga mengalami peningkatan. Adapun peningkatan aktifitas siswa berdasarkan Tabel 1 yaitu pada Siklus I pertemuan pertama aktifitas siswa hanya mencapai $50 \%$, pada pertemuan kedua mencapai $67 \%$, sehingga rata-raata aktifitaas siswa pada Siklus I sebesar 59\%.

Adapun pada Siklus II, pertemuan pertama aktifitas siswa meningkat dari Siklus I yaitu mencapai $83 \%$ dan pada pertemuan kedua mencapai $100 \%$, sehingga dapat diambil kesimpulan pada Siklus II peningkatan aktifitas siswa mencapai 95\%. Untuk ketuntasan hasil belajar siswa pada Siklus I dan Siklus II, dapat dilihat pada Tabel 2.

Berdasarkan Tabel 2 diketahui pada Siklus I pertemuan pertama, nilai rata-rata hasil belajar siswa sebesar 72, dengan siswa yang tuntas sejumlah 21 anak, persentase yang dicapai pada pertemuan satu ini mencapai 52,5\%. Sedangkan pada pertemuan kedua nilai rata-rata hasil belajar siswa sebesar 74, dengan siswa yang tuntas mencapai 25 anak, dan ketuntasan belajar sebesar $62,5 \%$. Adapun pada siklus I, nilai rata-rata yang dicapai sebesar 73, dengan ketuntasan siswa mencapai 23 anak, dengan persentase 58\%.

Pada siklus II pertemuan pertama, nilai ratarata hasil belajar siswa mencapai 82 dengan jumlah siswa yang telah tuntas belajar mencapai 32, ketuntasan belajar siswa sebesar $80 \%$. Sedangkan

Tabel 1 Rekapitulasi Hasil Pengamatan Aktifitas Guru

\begin{tabular}{lcccccc}
\hline Hasil Penilaian & $\begin{array}{c}\text { Siklus I } \\
\text { Pert. 1 }\end{array}$ & $\begin{array}{c}\text { Siklus I } \\
\text { Pert. 2 }\end{array}$ & $\begin{array}{c}\text { Rerata } \\
\text { Siklus I }\end{array}$ & $\begin{array}{c}\text { Siklus II } \\
\text { Pert. 1 }\end{array}$ & $\begin{array}{c}\text { Siklus II } \\
\text { Pert.2 }\end{array}$ & $\begin{array}{c}\text { Rerata } \\
\text { Siklus II }\end{array}$ \\
\hline Aktivitas Guru & 63 & 75 & 69 & 88 & 100 & 94 \\
Aktivitas Siswa & 60 & 70 & 65 & 90 & 100 & 95 \\
\hline
\end{tabular}

Tabel 2 Rekapitulasi Hasil Belajar Siswa

\begin{tabular}{ccccccccc}
\hline Hasil & \multicolumn{4}{c}{ Siklus I } & \multicolumn{5}{c}{ Siklus II } \\
\cline { 2 - 9 } Penilaian & N. LKK dan Ev T & $\%$ & Kategori & N. LKK dan Ev T & $\%$ & Kategori \\
\cline { 2 - 9 } Pertemuan 1 & 72 & 21 & 52.5 & Cukup & 82 & 32 & 80 & Baik \\
Pertemuan 2 & 74 & 25 & 62.5 & Cukup & 84.0 & 37 & 92.5 & Sangat baik \\
\hline Rata-rata & 73 & 23 & 58 & & 83 & 35 & 87,5 \\
\hline
\end{tabular}


pada pertemuan kedua, nilai rata-rata hasil belajar siswa mencapai 84 dengan jumlah siswa yang telah tuntas belajar mencapai 37, ketuntasan belajar ssiswa sebesar 92,5\%. Adapun pada siklus II, nilai rata-rata yang dicapai sebesar 83 , dengan ketuntasan siswa mencapai 35 anak, dengan persentase ketuntasan belajar sebesar 87,5\%.

\section{Pembahasan}

Salah satu model pembelajaran yang cocok untuk mengatasi permasalahan tersebut adalah model pembelajaran inquiry. Hamalik (1991) menyatakan pengajaran berdasarkan inquiry adalah suatu model yang berpusat pada siswa di mana kelompok-kelompok siswa dihadapkan pada suatu persoalan atau mencari jawaban terhadap pertanyaan-pertanyaan di dalam suatu prosedur dan struktur kelompok yang digariskan secara jelas. Pada awal kegiatan pembelajaran yaitu pada siklus I dan siklus II, kegiatan yang dilakukan adalah: (1) guru mengucap salam, doa, kemudian memeriksa kehadiran siswa; (2) guru mengajak siswa untuk mengingat kembali pelajaran pada pertemuan minggu lalu; (3) guru menjelaskan kompetensi dasar pada kegiatan pembelajaran yang akan dilaksanakan; dan (4) guru menjelaskan tujuan pembelajaran yang akan dicapai.

Memasuki kegiatan inti, guru mengkondisikan kelas menjadi beberapa kelompok, masing-masing kelompok beranggotakan 5 siswa. Kemudian, masing-masing kelompok mendapatkan lembar kerja kelompok. Pada fase menyajikan pertanyaan, pada kegiatan ini, guru mengajukan beberapa pertanyaaan berupa permasalahan-permasalahan yang harus dipecahkan oleh siswa. Hal ini sesuai dengan pendapat Hamalik (1991:92) yang menyatakan bahwa pengajaran berdasarkan inquiry adalah suatu model yang berpusat pada siswa di mana kelompok-kelompok siswa dihadapkan pada suatu persoalan atau mencari jawaban terhadap pertanyaan-pertanyaan di dalam suatu prosedur dan struktur kelompok yang digariskan secara jelas.

Kegiatan membuat hipotesis atau jawaban sementara, dalam kegiatan ini guru memberikan kesempatan kepada siswa untuk membuat jawaban sementara dari pertanyaan-pertanyaan yang diajukan, tanpa melihat media pembelajaran, ataupun sumber-sumber belajar yang lain. Kegiatan selanjutnya adalah pada fase nmerancang percobaan (pengamatan), masing-masing kelompok diminta untuk merancang kegiatan atau cara-cara sebelum mengerjakan lembar kerja. Guru dalam kegiatan ini berperan sebagai pembimbing dalam merancang kegiatan tersebut. Hal ini sesuai dengan pendapat Sanjaya (2009:43) yang menyatakan bahwa dalam pembelajaran inquiry terdapat prinsip interaksi, yaitu proses pembelajaran pada dasarnya adalah proses interaksi, baik interaksi antara siswa maupun interaksi siswa dengan guru bahkan antara siswa dengan lingkungan. Pembelajaran sebagai proses interaksi berarti menempatkan guru bukan sebagai sumber belajar, tetapi sebagai pengatur lingkungan atau pengatur interaksi itu sendiri.

Setelah kelompok selesai merancang percobaan (pengamatan), selanjutnya adalah melakukan percobaan (pengamatan) untuk memperoleh informasi, dalam fase ini, siswa mengamati media berupa media pembelajaran yang disajikan oleh guru baik di depan, maupun pada lembar kerja. Dalam menyelesaikan pekerjaannya, siswa menggunakan sumber belajar baik dari perpustakaan sekolah ataupun sumber-sumber dalam menemukan jawaban dari sebuah permasalahan, dalam kegiatan ini guru membimbing setiap kelompok. Hal ini sesuai dengan pendapat Mulyasa (2008:235) yang menyatakan bahwa inquiry adalah cara menyadari apa yang telah dialami. Sistem belajar mengajar ini menuntut peserta didik berpikir. Metode ini menempatkan peserta didik pada situasi yang melibatkan mereka pada kegiatan intelektual dan memproses pengalaman belajar menjadi sesuatu yang bermakna.

Kegiatan selanjutnya adalah mengumpulkan dan menganalisis data: siswa mencatat hasil pengamatan dalam lembar kerja kelompok yang telah disediakan. Kemudian masing-masing kelompok mengirimkan wakilnya untuk ke depan kelas membacakan hasil diskusinya untuk dibahas secara bersama-sama. Dan berikutnya adalah kegiatan membuat kesimpulan: pada fase ini, siswa dengan bimbingan dari guru diminta untuk membuat kesimpulan dari hasil pembelajaran yang telah dilakukan. Guru memberikan klarifikasi sebagai pemantapan jawaban diskusi kelompok. Langkahlangkah pelaksanaaan pembelajaran dengan model inquiry tersebut sependapat dengan Gulo (2005:109) yang menyatakan bahwa model inquiry berarti suatu 
rangkaian kegiatan belajar yang melibatkan secara maksimal seluruh kemampuan siswa untuk mencari dan menyelidiki secara sistematis, kritis, logis, analitis, sehingga mereka dapat merumuskan sendiri penemuannya dengan penuh percaya diri.

Berdasarkan hasil penelitian diperoleh peningkatan aktivitas belajar siswa ini dapat dibuktikan yaitu pada kegiatan siklus I mencapai $66 \%$, dan $82,5 \%$ pada Siklus II. Hal ini sesuai dengan teori yang dikemukakan oleh Sanjaya (2009), yang menyatakan proses pembelajaran inquiry pada dasarnya adalah proses interaksi, baik interaksi antara siswa maupun interaksi siswa dengan guru bahkan antara siswa dengan lingkungan. Pembelajaran sebagai proses interaksi berarti menempatkan guru bukan sebagai sumber belajar, tetapi sebagai pengatur lingkungan atau pengatur interaksi itu sendiri.

Keberhasilan kegiatan pembelajaran dengan model pembelajaran inquiry di Kelas V SDN Rembang 2 Kota Blitar, telah membuktikan bahwa penerapan model pembelajaran Inquiry memiliki kelebihan. Hasil penelitian ini juga didukung oleh hasil penelitin Mashudi (2011) yang menyatakan penggunaan metode inkuiri dapat meningkatkan aktivitas dan hasil belajar siswa kelas IV SDN Sukoharjo 2 Kota Malang. Menurut Sanjaya (2009:60) menyatakan bahwa model pembelajaran inquiry memiliki beberapa ciri utama diantaranya model inquiry menekankan pada aktivitas siswa secara maksimal untuk mencari dan menemukan, artinya model inquiry menempatkan siswa sebagai subjek belajar. Dalam proses pembelajaran siswa tidak hanya berperan sebagai penerima pelajaran melalui penjelasan guru secara verbal, akan tetapi mereka berperan untuk menemukan sendiri inti dari materi pelajaran itu sendiri.

\section{KESIMPULAN DAN SARAN}

\section{Kesimpulan}

Berdasarkan hasil pelaksanaan penelitian dan pembahasan tentang penerapan model pembelajaran inquiry dalam meningkatkan hasil belajar pendidikan kewarganegaraan pada siswa Kelas V, maka dapat disimpulkan: (1) penerapan model pembelajaran inquiry dalam kegiatan pembelajaran dilakukan sesuai dengan langkahlangkahnya, dapat meningkatkan aktifitas guru dan siswa. Adapun peningkatan aktifitas guru yaitu ada siklus I aktifitas guru mencapai $69 \%$ dan pada siklus II meningkat menjadi 94\%. Sedangkan pada aktivitas siswa, siklus I mencapai 65 dan pada siklus II mencapai 95\%; dan (2) model pembelajaran inquiry dapat meningkatkan hasil belajar siswa. Hal ini terlihat dari perolehan nilai rata-rata hasil belajar siswa yang mengalami peningkatan secara bertahap mulai dari Siklus I sebesar 73, dan pada siklus kedua menjadi 83. Selain itu, peningkatan kemampuan siswa dalam kegiatan pembelajaran terlihat dari persentase ketuntasan belajar siswa. Pada tahap Siklus I, sebesar 58\%, dan pada siklus II, persentase ketuntasan belajar siswa 87,5\%.

\section{Saran}

Berdasarkan hasil penelitian saran yang diajukan bagi peneliti selanjutnya adalah agar lebih melihat realitas di lapangan tentang pembelajaran selama ini, maka untuk ke depannya peneliti berusaha agar tidak mengulangi kesalahan yang dilakukan guru selama ini dan dapat memberikan alternatif model pembelajaran salah satunya model pembelajaran inquiry. Bagi guru agar menerapkan model pembelajaran inquiry ini dapat dijadikan sebagai salah satu alternatif model pembelajaran yang dapat meningkatkan hasil belajar siswa. Dalam pembelajaran sebaiknya memberikan metode-metode pembelajaran yang bervariasi, sehingga siswa tidak bosan dan meningkatkan keaktifan siswa dalam belajar.

\section{DAFTAR RUJUKAN}

Arikunto, S. 2007. Penelitian Tindakan Kelas. Jakarta: PT Bumi Aksara.

Bruce, J., \& Cleaf, K.1991. Succesfull Teaching. Bandung: Jemmars.

Djamarah, S. B., \& Zain, A. 1995. Strategi Belajar Mengajar. Jakarta: PT Rineka Cipta.

Gulo, W. 2005. Strategi Belajar Mengajar. Jakarta: Grasindo.

Hamalik, O. 2008. Kurikulum dan Pembelajaran. Jakarta: PT Bumi Aksara.

Mashudi, P. K. 2011. Peningkatan Hasil Belajar Pendidikan Kewarganegaraan melalui Model Pembelajaran Inquiry pada Siswa Kelas V Sekolah Dasar Negeri Bendogerit 1 Kota Blitar. Skripsi tidak diterbitkan. Malang: 
Fakultas Ilmu Pendidikan Universitas Negeri Malang.

Mulyasa, E. 2008. Menjadi Guru Profesional Menciptakan Pembelajaran Kreatif dan Menyenangkan. Bandung: PT Remaja Rosdakarya.
Sanjaya, W. 2009. Kurikulum dan Pembelajaran. Prenada Media. Jakarta

Tim Puskur. 2006. KTSP Kurikulum Tingkat Satuan Pendidikan. Jakarta: Depdiknas. 